\title{
Research on Teaching Reform of NC Technology Application Course
}

\author{
Chunfen Gong ${ }^{1}$ \\ ${ }^{I}$ Jiangxi Vocational Technical College of Industry \& Trade, Jiangxi, Nanchang, 330038 \\ 739960103@qq.com

\begin{abstract}
in recent years, with the rapid development of all aspects of our country, the demand for talents in various industries is growing, but also put forward certain requirements for the quality of talents. In recent years, China's manufacturing level has been continuously improved, and numerical control technology is the basic content of modern manufacturing technology. As a talent training base, colleges and universities should focus on cultivating students' ability in numerical control technology, constantly reform and optimize the teaching methods, implement exploratory analysis and modification of the scheme, and put the scheme into practice. On this basis, this paper puts forward some suggestions from the following three aspects to realize the teaching reform of numerical control technology application course, so as to provide analysis and research for professionals.
\end{abstract}

Keywords: numerical control technology, discussion and practice, teaching reform, strategy research

\section{对数控技术应用课程教学改革的探究}

\author{
龚春芬 1 \\ '江西工业贸易职业技术学院 江西 南昌 330103 \\ 739960103@qq.com \\ 摘要: \\ 近年来, 随着我国各方面的迅速发展, 各行业对人才的需求越来越大, 同时也对人才质量提出了一定的要求。 \\ 近年来我国制造水平不断提升，而数控技术是现代制造技术的基础性内容，作为人才培养基地的高校，应该重 \\ 点培育学生在数控技术能力, 不断改革和优化课程教学方式, 对方案实施探索性分析并修改, 同时将方案付诸 \\ 于实践。在此基础上，本文针对实现数控技术应用课程教学的改革，从以下三个方面提出了几点建议，以此供 \\ 专业人士进行分析与研究。
}

关键词: 数控技术; 探讨和实践; 教学改革; 策略研究

\section{1.引言}

数控技术的应用有效推动了制造业的发展, 近年 来, 在我国科技快速发展的背景下, 数控技术的应用 更加成熟, 在一定程度上标志着我国制造业发展的整 体水平, 数控机床的应用范围也越来越广泛, 数控机 床技术的普及提高了我国的就业率, 对专业性人才的 需求也日益增加。各高校在开展教学活动时, 应该重 视对数控技术专业人才的培育, 开设数控技术方面的 有关课程, 另外, 要不断优化并创新课程内容及模式, 提高学生的学习效率与学习能力, 从而提高人才培养 的质量。

\section{2.丰富教学方式，激发学习热情}

\section{1 创新教学方式}

要想推进数控技术应用课堂教学的改革进程, 首 先就要创新教学方式。步入 21 世纪以来, 很多高校 在各个学科上应用了启发式教学方法, 得到了很好的 反馈和效果。该方式本着以人为本的教学原则, 在设 置教学内容时, 依据了每位学生的个人素养和需要, 提升了学生的学习主动性, 让学生快速得把握课堂知 识, 让学生在自主学生的过程中得到全面发展, 形成 完善的思维方式, 增强学生各方面的能力。 
为了推动该种学习方式的顺利进行, 教师应该详 细了解学生的内在需求与实际状况, 充分结合学生的 年龄特征, 学生在学习过程中有着清晰的认知意识、 较强的接受能力以及较快的学习速度, 面对所有事物 都存在着较强的好奇心, 但是因为性格较为懒惰, 主 动学习的意识较弱, 缺乏探索知识的动力。

\section{2 在教育活动中要加强教师对数控技术的认 识与了解}

教师应该对数控技术有着清晰的认识与了解, 数 控技术是一门综合性学科, 包含各类技术内容, 在进 行操作的过程中存在着一定的难度, 给教学活动的开 展造成一定程度上的困难, 如果学生想要熟练掌握数 控技术, 那么便要丰富自身知识储备, 为了实现该目 标, 教师在开设课程时需要设置部分先修课程, 比如 《自动原理控制》等, 实现课程内容教学的层次化、 系统化, 逐步引导学生进行专业知识方面的学习。

\section{3.利用现代信息技术，改进教学模式}

为使课程开展的更加顺利, 要科学合理得安排教 学模式。当前社会对人才的需求越来越高, 传统的教 学模式已然无法适应其需求。随着我国科学技术的稳 定发展, 互联网技术也逐渐普及到了教育领域, 多媒 体因其独特的优点被应用在教学模式和方法中。为提 升学生的学习质量和效率, 培养更高素质的人才, 教 师在借助多媒体进行教学改革和创新时要注意以下 几点:

\section{1 创新多媒体技术内容}

多媒体在教学中的优点主要是将知识快速且大 量的传授给学生, 但是不是将课本知识全盘传授给学 生。教师在制作多媒体课件时, 不能直接将课本内容 复制到课件上。多媒体课件要尽可能以吸引学生注意 力和兴趣为目的, 从而达到传授知识的课堂效果。若 只是将多媒体课件作为课本内容展示的手段, 那么多 媒体技术的引进是毫无意义的。

\section{2 突出教学重点}

教师在进行课件内容展示时, 要将本课堂的重难 点标注出来, 让学生清楚得了解本节课的学习内容。 第三, 增强课件内容的互动性。教师在设置数控技术 应用课堂教学软件时, 可以设置一些具有互动性的问 题或课堂活动。不仅能增强学生之间的互动性和交流 行, 而且能拉进学生之间的距离, 提升了学生的课堂 参与, 激发学生对课堂的学习热情, 从而实现课堂效 率和质量的提升。

\section{4.充分利用软件，提高教学水平}

\section{1 教师要充分认识软件的益处}

老师在对于数控技术应用课程进行革新期间，应 该要了解到相关软件的使用, 经过运用相关的软件可 以强化教师的教学质量, 让学生可以迅速了解所学知 识内容。尽人皆知, 数控技术应用课程是可以将理论 知识和实践活动相结合的教学课程, 二者对于专业教 学来说都是必不可缺的, 教师一定要同时抓紧两个方 面, 确保可以使学生在实践教学过程中掌握如何将理 论知识和实践内容进行转换的方法。

\section{2 在理论与实践教学中充分利用好软件}

学校在为进行学生实践课程排课期间, 首要的是 需要保障课时数量, 让学生可以在丰富的时间内学习 实践操作技能, 需要保障实践课程中教师的教学质量 水平，一些院校因为缺乏资金的投入，导致教学实验 设备不完善, 数控机床数量少, 学生的实践机会较少, 面对这种现状, 学校可以购买数控编程半实物仿真模 拟系统, 利用这种系统, 学生可以执行部分显示操作 像是编程等。使学生利用现实的数控面板进行完整的 实践操作流程, 对于学生的未来发展起到了推动作用。

总之, 将数控软件应用到数控教学中可以提高教 学质量, 但是由于学校在数控专业的教育目的上, 是 关注实用性, 因此在培养过程中我们应从严、从难、 从实战出发在保证学生具备相应的基本理论之后应 使学生掌握过硬的操作技能。为了实现这一目标, 我 们必须在教学过程中科学有效地运用数控软件来促 进教学质量的提高, 同时教师应积极考虑软件在教学 过程中应用是所产生的问题, 并主动采取行动, 加以 解决。通过采取措施不断改进教学方法, 以提供最佳 的数控教学效果。

\section{5.发挥学生的主体地位、培养学生自主学习能 力}

\section{1 深刻认识学生的主体地位与有意识的培养 学生自主学习能力}

在课堂活动中, 学生处在主体位置上, 教师发挥 着不可忽视的指导作用, 学生和教师之间的关系是不 能颠倒的。要想更好的对数控技术教学进行变革, 将 学生放在主体位置, 帮助学生养成自主学习的习惯。 在教育教学实践中, 教师始终扮演着引导者的角色, 因此, 教师要做好本职工作, 帮助学生养成自主学习 知识的习惯, 最大程度地调动出学生的主动创新性, 让学生学会使用一点点学习、探索知识的学习方法, 增强学生在综合学习方面的能力, 让学生学会依靠合 作去发现新的知识, 并不是单纯把死板的理论知识教 授给学生。数控技术是比较有难度的学科, 综合性是 很强的, 要把学生放在主体位置上, 鼓励学生积极主 
动地获得相关的知识, 并在探索研究中掌握学习能力。 另外, 学生在积极探索学习的时候, 还相对的培养学 生的思维能力, 这样的做法与我国的教育目标相符合, 同时还能推动学生全方位的发展。

\section{2 从具体实例中出发, 培养学生自主学习能 力}

要想提高学生的自主学习水平, 就要让学生积极 主动的预习课本内容。学生依靠开展预习, 对本节课 中的学习知识点具有充分的了解, 同时在预习的时候, 还能找到自己记得不足和不懂的知识, 让学生在课堂 上可以有重点的听课, 积极开展预习不但可以让学生 更好地融入课堂教学活动中, 还能让学生养成积极参 与的行为习惯。使用预习的学习方法, 可以强化学生 的学习动机, 最大程度地提高学生的学习热情。与此 同时, 教师可以根据学生的预习情况, 了解学生的疑 惑以及学生在学习方面的短板, 对学生开展具体的、 有针对行的教学。依靠自主学习和发挥学生主体位置, 还可以使学生提出自己的疑惑, 自主学习是一个分析 和研究学习内容的过程。学生可以根据自己心中的疑 惑问题, 提出自己的见解, 或者是直接讲出自己的疑 惑问题, 在课堂活动中找出准确答案。另外在自主学 习的过程中产生疑惑问题, 还能培养学生养成积极探 索的精神。在学生自主学习的时候, 教师和学生之间 可以开展讨论, 教师肯定学生的正确观点, 指出并纠 正学生的错误观点, 消除学生心中的疑惑问题, 另外 还能根据学生的自主学习状况获取相关学生的相关 信息, 让学生充分发挥出内在潜力, 提高数控技术应 用课程教育教学水平。

\section{6.侧重于实验启发式教学手段}

\section{1 教育工作者要着重运用实验启发式教学手 段}

数控技术应用课程教学的改革与实践, 除了在教 学上丰富教学方式, 激发学生的学习热情、利用现代 信息技术, 改进教学模式、利用软件, 提高教学水平 以及发挥学生的主体地位、培养学生自主学习能力上 的方式外, 还需要高校在数控教学中, 侧重于实验启 发式教学手段。

在对数控技术专业进行课程教学过程中, 教师不 可以只采用单一化, 枯燥乏味的手段进行知识授课, 应该要和同学们发展出一个良好的互动教学模式, 发 展学生的思考能力, 引导学生进行问题解析, 思路了 解等, 将教学内容和学生所学知识相融合, 从而形成 启发式教学的教学手段和教学目的。但启发式教学不 只是采取在教材课堂中教师提问这种单一的教学方 法, 而是重视对学生的思维能力的培养, 扩展问题, 深入了解知识内容, 将所要进行研究的问题符合于教 师的教学内容、教学目的和教学方向, 不可以毫无瓜 葛的对问题进行思维扩展, 一定要基于所学知识进行
互动交流。在数控技术专业的课堂教学过程中, 教师 可以把教学内容和自身的研究成果相结合, 使用启发 式的教学手段。如今, 在世界范围内的电子信息技术, 互联网技术得到了质的飞跃，一些教师在自身相关领 域都会小有成就, 因此在教学课堂中, 教师可以推动 学生对于数控技术未来的发展进行研究探讨, 发展学 生的思维能力, 丰富学生的专业知识, 还可以对比多 个国家的科技技术的数控技术之间的异同, 调动学生 的学习积极性和主动性。

\section{2 从具体实例中出发, 运用实验启发式教学 手段}

例如: 一些同学喜欢研究和了解与机器人相关的 技术, 对于这种情况, 教师就可以使用启发式教学方 式, 引导学生去思考机器人和数控技术在智能操作方 面存在哪些差异和相似之处, 组织学生以小组的形式 进行讨论, 以此来提高学生的思考能力, 达到理想中 的课堂效果。为了达到启发式教学的教学目的, 教师 可以为学生讲解相关的科研成果, 为学生分析总结出 数控技术与其他技术的不同之处和相似之处, 使学生 了解到它们二者之间的关系。但启发式教学方式的教 学效果如何能被展现出来? 现阶段大部分教师都通 过布置作业的方式来观察教学效果, 比如: 教师提出 一个与数控技术相关的问题, 学生在课下可以进行小 组讨论, 可以阅读以往的科研报告, 所以, 学生的作 业质量可以反映出启发式教学方式的教学效果。在学 生完成作业的过程中, 学生会通过多种方式来进行思 考, 这样可以提高学生的思考能力、专业素养和交流 合作能力, 从而达到启发式教学的教学目的。除此之 外, 教师还可以通过随堂测试的方式来检验教学成果。

\section{7.结论:}

步入二十一世纪以后, 随着数控技术的不断进步, 与数控专业相关的教学内容也需要不断变革和创新。 对数控技术应用课程进行变革和创新, 不仅可以提高 学生的专业素养和实践能力, 推动学生全方面发展, 为学生营造良好的课堂氛围和学习环境, 使学生可以 积极主动地进行学习数控技术, 以此来提升学生的学 习能力和创新能力; 还可以提高数控专业的课堂质量, 完善数控专业的教学体系。但现阶段数控技术应用课 程还需要继续变革和创新, 为了培养出更多的高素质 的综合型数控人才, 教师需要不断创新自身的教学方 式, 提高自身的专业能力和教学水平, 紧跟时代发展 的潮流, 积极响应改革的要求, 在培养人才的过程中 贡献出属于自己的力量, 推动改革可以顺利开展。

\section{REFERENCES}

[1] Xie Weirong. Teaching reform and practice of numerical control technology application course [J]. Computer products and circulation, $2019(05)$ : $169+286$ 
[2] Wang Quanlong, Wu Meiping, Lu Yanming. Research on teaching reform of CNC technology course for "made in China 2025" [J]. Education and teaching forum, 2018 (37): 96-98

[3] Shao Minmin, Dong Baolian, Zhang Nan. Research on teaching mode of flipped course based on MOOC -- Taking "database foundation and application" course as an example [J]. Education and teaching forum, 2019,0 (37): 213-214

[4] Chen Zuliang, Wu Lianneng, Huang Jianning. Practical research on practical teaching mode of secondary vocational students majoring in numerical control based on Rosenthal Effect -Taking the questionnaire survey report of numerical control students in our university as an example $[\mathrm{J}]$. Education sector: higher education, 2019,0 (7): 100-101

[5] Zhang Lijuan. Exploration and application of new teaching and learning mode for the basis and application of electrical technology -- Based on the combination of SPOC and "cloud classroom intelligent vocational education" [J]. Modern vocational education, 2019,0 (30): 180-181

[6] Wu Nan. Teaching reform and project design of "integration of teaching, doing and practice" for PLC technology course of CNC machine tools in Higher Vocational Colleges [J]. Journal of Kunming Metallurgy College, 2015,31 (5): 89-93

[7] Fan Jun, Chen Dehang. Teaching reform and practice of integrated classification and stratification in secondary and higher vocational education -- Taking numerical control technology major of Sichuan Vocational and Technical College as an example [J]. Journal of Jiamusi vocational college, 2015,0 (12): 15-16

[8] Wang Dan, Wang Lingyun, Zhou Libo, Cao Yongjie. Discussion on the teaching reform of mechanical mechanism and typical parts -- Taking the secondary and higher vocational training teaching of numerical control technology specialty as an example [J]. Science and technology information, 2015,13 (23): 178-179

[9] Shi Weiping. The current development trend of Higher Vocational Education in the world and Its Enlightenment to China $[\mathrm{J}]$. Higher Vocational Education: Journal of Tianjin Vocational University, 2003 (5): 17-19

[10] Li Xiangwei, Zhou Wenling, Huang Weiming. Reform and practice of the teaching mode of "integration of teaching and doing" in the course of modern pneumatic technology and PLC in Higher Vocational Colleges [J]. Journal of
Guangdong Polytechnic of light industry, 2010,9 (1): $23-25$

[11] Luo Wen, Zhu Guojun, Wang Wenjie. Practice and exploration of integrated teaching mode of PLC control system analysis and practice [J]. Journal of Changsha Aviation Vocational and technical college, 2011,11 (4): 17-20

[12] Lei Honghua. Realization of teaching method of "integration of teaching, learning and doing" -Taking the course reform of PLC industrial control as an example [J]. Journal of Xiangyang vocational and technical college, 2014,13 (5): 126-129

[13] Liu Fulu. Discussion on the practice of "integration of project teaching and practice" in the course of electrical control and PLC [J]. Journal of Chongqing Polytechnic of industry and trade, 2011,0 (1): 61-64

[14] Fang tingling, Cao Han, Wang Changying. A preliminary study on the intelligent classroom teaching mode based on wechat public platform - Taking the course of "database principle and application" as an example [J]. Industry and information education, 2017,0 (3): 77-83

[15] Yang Feng, Xue Maoquan, Bai Jianbo. Exploration and practice of practical teaching of reflective lean concept -- Taking NC machining practical training as an example $[\mathrm{J}]$. Market of science and technology economy, 2018,0 (9): $138-140$

[16] Jiang Yang, Yang Jing, Tang Bo, Wang Shuai, Ma Yuchao, Zhang Juan. Reform of NC practice teaching mode based on integration of project and virtual simulation $[\mathrm{J}]$. Laboratory science, 2018,21 (4): 173-175 